surface, thus giving an opportunity for hydrophobic interaction in molecules that otherwise appear able to adopt a purely polar exterior conformation. Future attempts to relate protein composition with protein properties in solution should consider those classes of proteins with more extreme solubility properties and include the seed proteins and the protamines and histones.

C.S.I.R.O. Wheat Research Unit,

North Ryde,

New South Wales.

1 Tanford, C., J. Amer. Chem. Soc., 84, 4240 (1962).

Fisher, H. F., Proc. U.S. Nat. Acad. Sci., 51, 1285 (1964).

${ }^{3}$ Hatch, F. T., Nature, 208, 777 (1965).

'Anon., J. Physiol., 37, 32 (1908); Amer. J. Physiol., 21, xxvii (1908).

s Wu, Y. V., and Dimler, R. J., Arch. Biochem. Biopnys., 103, 310 (1963).

${ }^{6}$ Jones, R. W., Babcock, G. E., Taylor, N. W., and Senti, F. R., Arch. Biochem. Biophys., 94, 483 '(1961).

'Winzor, D. J., Biochim. Biophys. Acta, 74, 144 (1963).

'Taylor, N. W., and Cluskey, J. E., Arch. Biochem. Biophys., 97, 399 (1962),

- Nemethy G., and Scheraga, H. A., J. Phys. Chem., 66, 30 (1962).

\section{Facilitated Diffusion in Mouse and Rat Erythrocytes}

THE discussion of the effect of narcotics on the permeability of erythrocytes which appears in some text-books ${ }^{1 \sim 3}$ is based on a report by Jacobs and Parpart. These authors showed that $n$-butyl alcohol decreased the permeability of erythrocytes of curtin species to glycerol and increased the permeability to glycerol in the erythrocytes of other species. In all cases reported, butanol increased the permeability to thiourea. Davson suggests in several of his writings (for example, ref. 2) that narcotics decrease the permeability "in certain special cases of erythrocyte permeability ... [of] . . . those substances that apparently show an unusually rapid rate of penetration". Similar results were reported by Hunter et $a l .^{5}$, and it was suggested that a carrier mechanism, or facilitated diffusion, was involved in these "special cases".

These data might suggest that glycerol crosses the membrane of some erythrocytes by facilitated diffusion and crosses others by simple diffusion but that thiourea always crosses by simple diffusion. That this might not always be the case is suggested by the results of Jacobs et al. ${ }^{6}$. They reported a series of quite obvious differences between the permeability of the red cells of rats and mice. One of these differences was the rather rapid rate of penetration of thiourea into mouse cells as compared with rat cells. Since these data suggest that the thiourea permeability of mouse erythrocytes might be another example of a "special case", the present experiments were performed to chcck this point.

Rat (Rattus rattus and $R$. norvegicus) and mouse (Mus musculus) blood were obtained by decapitation, the blood being collected in a large volume of isotonic, phosphatebuffered sodium chloride solution without anticoagulant. The cells were washed three times with this solution. Permeability measurements were made using a densitometer ${ }^{7}$. A portion of mouse cells was added to $0.3 \mathrm{M}$ thiourea in water with and without butanol and the rate of haemolysis was measured at $0^{\circ} \mathrm{C}$. Since the permeability of rat cells to thiourea is considerably lower, it was possible to use volume-change measurements with these cells. They were equilibrated in a solution of $0.3 \mathrm{M}$ thiourea in buffered, isotonic sodium chloride. The rate of exit was measured by adding a portion of these equilibrated cells to a hypertonic solution of sodium chloride with or without butanol.

Typical results are shown in Fig. 1. A comparison of curves 1 and 2 shows the inhibitory effect of $0.1 \mathrm{M}$ butanol on the rate of haemolysis of mouse cells in thiourea. A comparison of curves 3 and 4 shows the accelerating effect of $0.2 \mathrm{M}$ butanol on the rate of exit of thiourea from rat cells. The erythrocytes of both species of rats gave the same qualitative results. The increase in permeability of

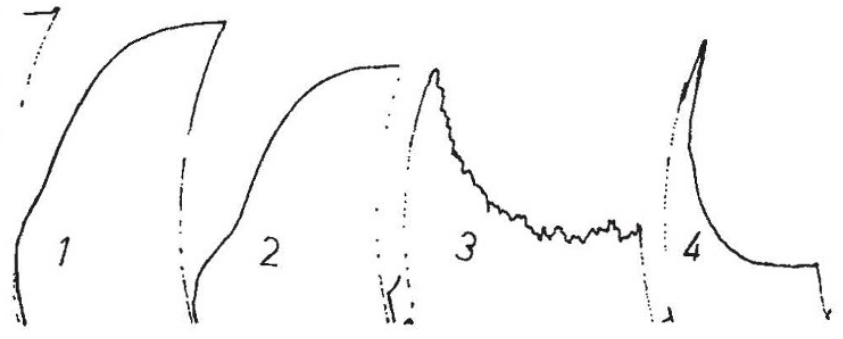

Fig. 1. Effect of butanol on the permeability of mouse and rat erythrocytes to thiourea. 1, Haemolysis of mouse cells in $0.3 \mathrm{M}$ thiourea. 2. Haemolysis of mouse cells in $0.1 \mathrm{M}$ butanol in $0.3 \mathrm{M}$ thiourea. 3 chloride solution thiourea, in $0.2 \mathrm{M}$ butanol in sodium chloride solution

rat cells to thiourea in the presence of butanol has already been reported ${ }^{4}$. The decrease in the permeability of mouse? cells to thiourea in the presence of butanol has not becn reported, but is what would be expected if the permeability of these cells to this non-electrolyte represents another example of a "special case" of permeability.

Other data included by Jacobs et al. ${ }^{6}$ suggest that in addition to glycerol ${ }^{4}$, ethylene glycol and urea permeability in rat cells represent additional "special cases". To te st this point the effect of butanol on the permeability of these cells to the three non-electrolytes was also investigatrd. Concentrations of 0.1 and $0.2 \mathrm{M}$ butanol were investigated. Glycerol permeability was measured using the shrinking technique at $30^{\circ} \mathrm{C}$. Ethylene glycol permeability was measured at $0^{\circ} \mathrm{C}$ by both the shrinking and haemolysis techniques, while haemolysis measurements at $0^{\circ} \mathrm{C}$ were used to investigate the permerbility to urca. Relative times were calculated by dividing half the total time for the experimental curve by half the total time for the control eurve. Thus, a relative time greater than unity indicates a decrease in permeability, while a relative time less than unity indicates an increase. The following relative times were obtained: glycerol, $6 \cdot 3$; ethylene glycol, shrinking, $3 \cdot 7$; haemolysis, $2 \cdot 4$; and urea, $1 \cdot 4$.

These data indicate that the permeability of at least mouse erythrocytes to thiourea is decreased by butanol just as this substance decreases the permeability of red cells of several species to glycerol. In addition, butanol decreases the permeability of rat cells to glycerol, ethylene glycol and urea. According to the interpretation suggested in ref. 5 , facilitated diffusion appears to be involved in these four cases. Thus, to Fig. 8 of ref. 5 a right-handed symbol (facilitated diffusion-butanol inhibition) should be added to the urea group for the rat, to the ethylene glycol group for the rat, to the thiourea group for the mouse and to the glycerol group for the rat.

The experiments were performed in the Biology Department, University of the Andes, Bogotá, Colombia. We thank the Rockefeller Foundation for a grant in support of this work.

Departamento de Biologia,

Bertha Ospina

Universidad Javeriana,

Bogotá, Colombia.

Departamento de Biología,

F. R. HUNTER

Centro Experimental de Estudios Superiores,

Barquisimeto, Venezuela.

'Davson, H., and Danielli, J. F., The Permeability of Natural Membranes, second ed. (University Press, Cambridge, 1952).

2 Davson, H., A Textbook of General Physiology, second ed. (Little, Brown and Company, Boston, 1959).

${ }^{3}$ Giese, A. C., Cell Physiology, second ed. (W. B. Saunders Company, London, 1962).

4 Jacobs, M. H., and Parpart, A. K., Biol. Bull., 73, 380 (1937).

${ }^{5}$ Hunter, F. R., George, J., and Ospina, B., J. Cell. Comp. Physiol., 65, 299 (1965).

- Jacobs, M. H., Glassman. H. N., and Parpart, A. K., J. Cell. Comp. Physiol., $11,479(1938)$

'Hunter, F. R., .J. Cell. Comp. Physiol., 55, 175 (1960). 